\title{
Nature of the SME Financing Gap: Some Evidence from Ghana
}

\author{
Daniel Domeher ${ }^{1}$, Joseph M. Frimpong ${ }^{1} \&$ Kwame Mireku ${ }^{1}$ \\ ${ }^{1}$ Dept. of Accounting and Finance, KNUST, Ghana \\ Correspondence: Daniel Domeher, Department of Accounting and Finance, KNUST, Kumasi, Ghana. E-mail: \\ dommedann@yahoo.com or ddomeher.cass@knust.edu.gh
}

Received: March 17, 2014

Accepted: April 25, 2014

Online Published: June 25, 2014

doi:10.5539/ijef.v6n7p165

URL: http://dx.doi.org/10.5539/ijef.v6n7p165

\begin{abstract}
SMEs are pivotal to economic growth globally. They are however, often said to be constrained by the lack of or limited access to funding. Despite this assertion, the nature of the credit constraint problem is not well known in Ghana especially regarding its various dimensions. Knowing these dimensions is critical to formulating appropriate policies to deal with the problem. The purpose of this paper is to provide empirical evidence on the various dimensions of the credit constraint problem in Ghana. The survey strategy of enquiry was employed based on the adoption of the direct method of determining credit constraints. It was observed amongst other things that the credit constraint is almost entirely a supply-side problem as the demand-side constraint is almost non-existent. It has been recommended amongst other things that intervention policies should focus on the very small business as the incidence and degree of constraint tends to be higher amongst them.
\end{abstract}

Keywords: financing gap, Ghana, SMEs

\section{Introduction}

Credit plays a major role in the economic development of the world's economies. Such a role is even more important in the developing countries where poverty exist in pandemic proportions. Improved access to credit is pivotal in channelling resources to more productive use and is an important mechanism for enhancing household incomes and livelihoods (Atieno, 2001). Increasing credit access helps economic units to take greater advantage of growth opportunities. Doubling the credit flow to the private sector could also cause a $2 \%$ increase in the GDP growth rate (Caprio \& Honohan, 2001) and as aptly argued by Melzer (2007) any disruption to the level of credit supply is capable of affecting the level of economic activities significantly. On the other hand, Domeher and Abdulai (2012a) argue that without the right property rights enforcing systems, adequate socioeconomic and legal infrastructure and macroeconomic policy framework, credit alone may fail to induce the productive investments required to promote growth and poverty reduction. Nonetheless, the role of credit in SME development continues to take centre stage in the literature.

The SMEs sector has often been described as the engine of growth in Africa. In the developing countries, it has been a major source of livelihood to most of the poor households. These small businesses usually are more labour intensive and highly linked to the local industries; they contribute to skill development in entrepreneurship and the spread of technology and as a result are very important in ensuring broad based economic growth on equitable basis (Bahar, 2001). SMEs account for over $60 \%$ of GDP and over $70 \%$ of total employment in low-income countries, while they contribute over $95 \%$ of total employment and about $70 \%$ of GDP in middle-income countries (Ayyagari, Beck, \& Demirgüc-Kunt, 2003). In Ghana, 85\% of manufacturing related employment comes from the SMEs; they contribute $70 \%$ to GDP, constitute $92 \%$ of all businesses and make up $80 \%$ of the private sector (Abor \& Quartey, 2010). Having said that there is no denying the fact that SMEs are continually besieged by several challenges which constrain their overall development. The most prominent of the problems is the difficulty SMEs have in accessing credit. Indeed, six out of the 10 countries where credit is most difficult to get are in Africa (The World Bank, 2006).

Even though there may be some more fundamental reasons for a business failing to start or progress, the lack of funds is often the most immediate reason (Abor \& Quartey, 2010). As a result of the credit constraint, the growth rate of small businesses is reduced by $10 \%$ and that of large businesses by $6 \%$ (Beck, Demirgüç-Kunt, \& Maksimovic, 2006c). It must be pointed out that the real problem is the extent of the credit constraint and not just the existence of the constraint itself. Hence, improved access to credit for SMEs is pivotal in the fight 
against poverty. As aptly observed by Claessens (2006), credit provides the ladder on which the poor can climb out of poverty. Though small enterprises in the developing countries are almost always associated with credit constraints, Berg (2010) argues that very little robust evidence of this exists. Also, though studies (cited earlier) have revealed that most SMEs are credit constrained, it is worth mentioning that there are various dimensions of the credit access problem and in Ghana, the exact nature of this constraint in terms of its various dimensions is not known. The aim of this paper therefore is to investigate the nature of the SME credit constraint problem in Ghana and examine the demand and supply side components. The rest of the paper is organised as follows: the theory of credit constraint is outlined in section two. The methodology and results and discussion are presented in section three and four respectively. Section five focuses on the conclusions and recommendations.

\section{Theory of Credit Constraint}

The World Bank (2008) describes access to finance as the absence of both price and non-price barriers to the actual use of financial services - credit. Credit access is thus multifaceted and According to Claessens (2006), the various dimensions could be described in terms of the degree of access reliability-whether credit can be obtained when needed; the convenience of access-ease of access and continuity in terms of ability to repeatedly access funds; affordability-cost of credit and flexibility-whether or not credit products are tailor made. Access to credit is affected by both demand and supply side factors. The demand side includes factors such as the desire or need to borrow. Demand for credit is determined by the desire to expand operations, profitability of investment relative to the cost of capital, availability and cost of other sources of funding (Bigsten et al., 2003). The supply side involves the decision of whether to lend or not and how much to lend (Chen \& Chivakul, 2008). A credit constraint exists wherever the desired level of credit is higher than the amount offered by the market (Ruiz-Tagle, 2005). When a firm is unable to borrow as much as it would like to at the going market rate, then the firm is credit constrained (Banerjee \& Duflo, 2004).

The concepts of imperfect information and market equilibrium are fundamental to the theory of credit constraint. Stiglitz and Weiss (1981) combine the two concepts to provide the following explanation of the theory of credit constraint. Starting from a state of equilibrium in the credit market, any increase in demand for credit will create disequilibrium as the credit demand curve shifts to the right (where demand exceeds supply). As a result, interest rate (price of credit) will be expected to rise to trigger a fall in demand or an increase in supply or both so as to re-establish equilibrium at a higher interest rate. The interest rate is thus assumed to be flexible both upwards and downwards. The flexibility of interest rate is expected to eliminate the excess demand for credit anytime there is a temporary distortion, re-establish equilibrium and remove any existing credit constraints.

In reality, there are limits on the extent to which lenders could raise the rate of interest which means the market could settle in disequilibrium. Information asymmetry distorts the credit market operations. Though lenders would like to raise interest rates to return the credit market to equilibrium whenever there is excess demand, doing so under information asymmetry would lead to adverse selection where only risky borrowers are attracted to apply for credit. The interest that borrowers are willing to pay is an indicator of their riskiness. The higher the rate they are willing to pay the more risky they are likely to be. Unfortunately, therefore, credit market interest rates cannot increase beyond a certain optimum point. There is an optimum rate of interest beyond which lenders will not supply credit. At this optimum interest rate, if demand exceeds supply, borrowers will be prepared to pay higher rates to obtain credit but raising the interest rate will reduce the expected returns of the lender. Secondly, the interest rates charged have an effect on the incentive to repay the loan. Higher interest may wipe out the expected returns accruing to the borrower. This motivates borrowers to undertake high risk projects with high pay-offs but low probability of success (moral hazard problem). Therefore, lenders cannot freely increase interest rates as a response to the rise in demand. The market may as a result settle in disequilibrium where demand outweighs supply even though some borrowers would have been willing to pay a higher interest rate to increase the supply of credit and remove any existing credit constraints. This is illustrated in the figure 1 below which shows that the maximum return that can accrue to the lender is achieved at the optimum interest rate of $\mathrm{r}^{*}$; any attempt to increase interest rate above this optimum will actually cause a decline in expected returns. Hence, at the optimal rate of interest shown above any increase in demand for credit will not be met creating a credit constraint. 


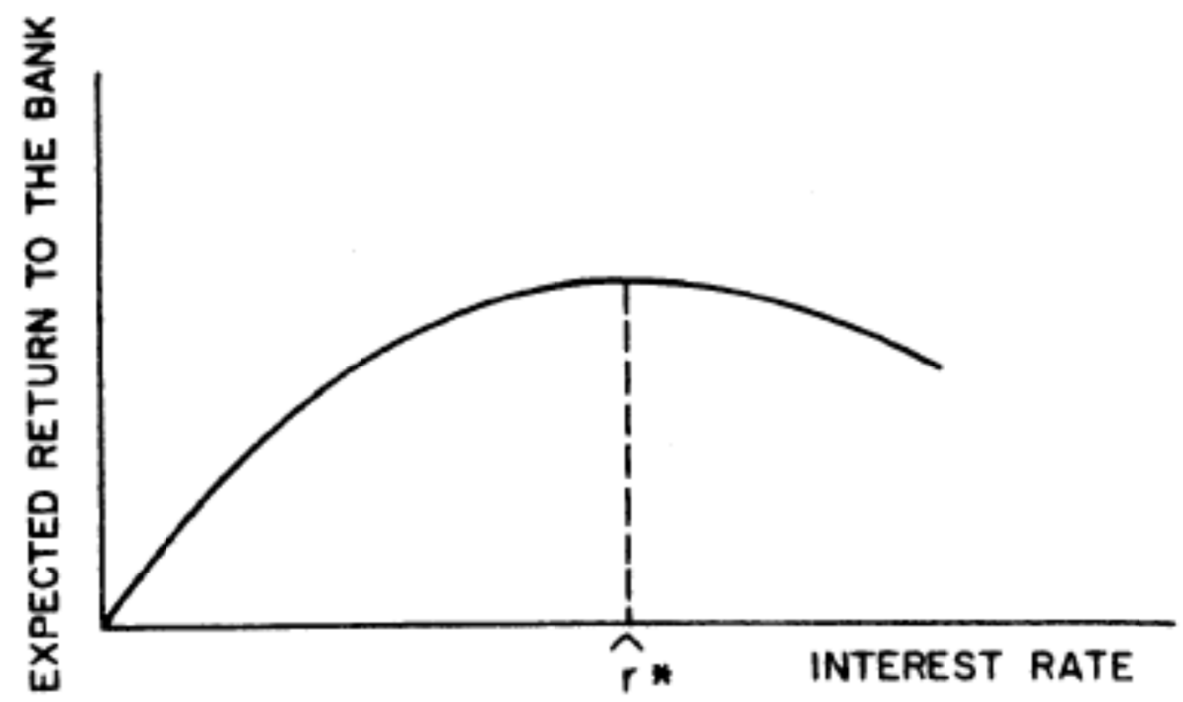

Figure 1. Interest rate and expected returns to banks

Source: Stiglitz and Weiss (1981).

\section{Methodology}

Overall, the quantitative methodology was adopted in the conduct of this research. The strategy of enquiry employed was the survey strategy. Kumasi (the capital city of the Ashanti region; widely regarded as the second largest commercial city in the country) was conveniently selected as the study area based on the researchers knowledge and familiarity with the city. Proprietors of small enterprises were the main participants in the surveys. The main businesses considered in the study were those related to services - trading/commerce as well as manufacturing-carpentry and mechanics. These were chosen because according to the Kumasi Metropolitan Assembly-KMA (2011), they are the dominant businesses in the city; trade alone accounts for $71 \%$ of employment followed by manufacturing $(24 \%)$. The traders in the city are mainly located in various markets (KMA, 2011). The traders in this study were selected from the two main markets-the Kumasi Central Market and the Adum Central Business District not only because they are the major markets but also because they are quiet easily accessible. The mechanics were also sampled from the famous Suame Magazine where small engineering based industries are sited specialised in vehicular parts production and servicing. Finally, the main sites for the woodworking industries specialised in the production of furniture are Anloga and Sokoban. Anloga was randomly selected for the study. Since there was no list of the businesses operating in each market or site visited, the researcher adopted a convenience sampling technique. On the day the researcher visited any site, individuals who were both willing and available to participate in the research were selected accordingly.

A combined total of 131 proprietors of small enterprises were involved in the survey. This study adopted the direct approach to detecting credit constraints by soliciting household perceptions on whether or not they are credit constrained (Love \& Sanchez, 2006). Structured interviews were conducted as most of the participants could not administer the questionnaires themselves. The reported credit market experiences of the participants within the past 2 years was used to determine if they are constrained and the nature of the constraint. The data collected was coded and entered into SPSS (version 17) and analysed descriptively; in addition, the chi-square test and Wilcoxon's test were also used to explore relationships. The participants were classified into those who had applied for credit and those who had not. Respondents who had applied for credit were considered not to face a credit constraint if they were able to obtain the full credit amount needed. However, those who applied for credit but were refused (either partially or completely) were considered to be constrained (supply side constraint). The other participants who had not applied for credit were further divided into two groups - the unconstrained and the constrained groups. Participants who did not apply for credit because they had no need for it were considered unconstrained whilst those citing any other reason were considered as constrained. Those that did not apply due to other reasons such lack of information were classified as demand side constrained and finally respondents who did not apply for credit because of reasons such as: high cost of credit, process inconveniences, 
lack of required documents and the lack of tailor made facilities were classified under supply-side constraint.

\section{Results and Discussions}

\subsection{Respondent Characteristics}

A summary of the respondents' characteristics can be found in Table 1 below. A total of 131 SME owners were involved in this survey; the sample consisted of 74 females (56.5\%) and 57 males (43.5\%). About $46.6 \%$ of respondents were between 30-45 years old. On the level of education, the results show that $23.7 \%$ have no formal education at all. Whilst $36.6 \%$ have only basic education, only $7.6 \%$ have tertiary education. The median number of dependants per respondent is $5-10(64.1 \%)$. Respondents were engaged in various businesses in the areas of trading, mechanics, carpentry and catering. Majority of participants (66\%) were into trading. Approximately $62 \%$ of respondents employ less than five people. These businesses reported median monthly cash generated of GHC 500-1000 (35\%) and a median monthly expenditure of GHC 300-500 (36\%). A little less than half of the respondents (45.8\%) identified funding as their most critical problem. The remaining $54.2 \%$ of the respondents reported other problems. Comparing the individual problems reported, the lack of funds emerged as the single most important problem.

Table 1. A summary of respondents' characteristics-small business owners

\begin{tabular}{|c|c|c|c|}
\hline & Categories & $\mathrm{N}=131$ & Valid \% \\
\hline \multirow[t]{2}{*}{ Gender } & Female & 74 & 56.5 \\
\hline & Male & 57 & 43.5 \\
\hline \multirow[t]{4}{*}{ Age } & $<30 \mathrm{yrs}$ & 21 & 16 \\
\hline & $30-45 y r s$ & 61 & 46.6 \\
\hline & $46-60 y r s$ & 36 & 27.5 \\
\hline & $>60 \mathrm{yrs}$ & 13 & 9.9 \\
\hline \multirow[t]{4}{*}{ Level of education } & No formal education & 31 & 23.7 \\
\hline & Basic education & 48 & 36.6 \\
\hline & Secondary/ technical/ vocational & 42 & 32.1 \\
\hline & Tertiary & 10 & 7.6 \\
\hline \multirow[t]{3}{*}{ Number of Dependants } & $<5$ & 33 & 25.2 \\
\hline & $5-10$ & 84 & 64.1 \\
\hline & $>10$ & 14 & 10.7 \\
\hline \multirow[t]{4}{*}{ Business type } & Trader & 87 & 66.4 \\
\hline & Mechanic & 17 & 13.0 \\
\hline & Carpenter & 14 & 10.7 \\
\hline & Catering & 13 & 9.9 \\
\hline \multirow[t]{3}{*}{ Number of employees } & $<5$ & 81 & 61.8 \\
\hline & $5-10$ & 37 & 28.2 \\
\hline & $>10$ & 13 & 9.9 \\
\hline \multirow[t]{4}{*}{ Cash generated per month } & $<500 \mathrm{GHC}$ & 25 & 19.1 \\
\hline & 500-1000 GHC & 46 & 35.1 \\
\hline & 1001-1500 GHC & 38 & 29.0 \\
\hline & $>1500 \mathrm{GHC}$ & 22 & 16.8 \\
\hline \multirow[t]{4}{*}{ Monthly expenditure } & $<300 \mathrm{GHC}$ & 33 & 25.2 \\
\hline & $300-500 \mathrm{GHC}$ & 47 & 35.9 \\
\hline & 501-700 GHC & 28 & 21.4 \\
\hline & $>700 \mathrm{GHC}$ & 23 & 17.6 \\
\hline
\end{tabular}

\subsection{Credit Market Experiences}

Respondents were asked to report whether they had applied for credit in past two years. The results show that about $72 \%$ of all 131 respondents (94 respondents) had participated in the credit market through the submission of credit applications at some point. There was however, no credit market activity reported by the remaining $28 \%$. This demonstrates a high need and demand for formal credit amongst small businesses in the study area contrary to findings elsewhere by Love and Sánchez (2009) that small enterprises have a very limited demand for formal credit. Elsewhere in rural Romania, it was also found that a very low participation rate $(20 \%)$ of small enterprises in the formal loans market exists (Chavez, Sanchez, Schor, \& Tesliuc, 2001). Given that this study was conducted in the urban centre, it was not surprising to find very high participation rates amongst small businesses because unlike business owners in the rural areas, a wide range of formal sources of finance are 
available to their counterparts in the cities.

The Chi square test conducted show there is no significant association between gender and the reported participation in the credit market $\left[x^{2}(1)=3.68, p>.05\right]$. This contradicts the findings that in rural Ghana, the demand for credit is lower for female headed households as they are often poorer than their male counterparts (Bendig, Giesbert, and Steiner, 2009). Also, the likelihood that a respondent had made a loan application in the past two years had no significant association with the respondent's age $\left[x^{2}(3)=6.77, p>.05\right]$; level of education $\left[x^{2}(3)=2.78, p>.05\right]$; number of employees $\left[x^{2}(2)=2.36, p>.05\right]$; monthly cash generated $\left[x^{2}(3)=1.95\right.$, $p>.05]$; and the most important business problem $\left[x^{2}(6)=2.04, p>.05\right]$; These results reiterate the argument that the key determinants of credit demand are the availability of a profitable business venture and the need to expand or finance working capital (Bigsten et al., 2003).

The 94 participants who had applied for loans (loan applicants) were asked to report where they submitted their applications. Most of them (41.5\%) applied for the credit from Savings and Loans Companies. About 34\% from Rural Banks, 21.3\% from the main Universal Banks and only 3.2\% from other institutions (credit unions). It was established that the institutions from which credit is being sought could influence success rate of the application as they tend to have different requirements. Compared to the Universal banks, the other institutions do have relatively less stringent requirements and they tend to take financial services to the door steps of these businesses making them the more convenient choice when credit is needed. Indeed, Atieno (2001) observes that non-bank financial institutions are the main sources of formal credit for small enterprises as their loan application procedures are shorter and loans tend to have longer maturities.

\subsection{Constraint Status of Loan Applicants}

To determine the constraint status of loan applicants, they were asked to indicate how much they applied for and the proportion of this amount they actually received. Only $7 \%$ of the applicants wanted to borrow amounts less than GHC 500 and about $27 \%$ wanted above GHC 2,000; 33\% of the loan applicants each wanted loan amounts of GHC500-1000 and GHC 1001-2000. The loan amount applied for had a significant association with the selected lending institution $\left[{ }_{x}^{2}(3)=13.61, p<.01\right.$. Cramer's $\left.V=.380, p<.01\right]$. For instance, $52 \%$ of the universal banks received applications for loan amounts in excess of GHC 2,000 compared to $18 \%$ of MFIs (See Table 2 below). Hence, business owners who required larger loan amounts are more likely to go to the universal banks. The other lenders (MFIs) tend to provide micro loans which may only increase gradually overtime as each loan amount is successfully repaid. Businesses that cannot wait to go through this process are most likely to approach a Universal Bank for credit.

Table 1. Crosstab between loan amount wanted and selected lending institution

\begin{tabular}{|c|c|c|c|c|c|}
\hline & & & \multicolumn{2}{|c|}{ Lending institution } & \multirow[t]{2}{*}{ Total } \\
\hline & & & Universal bank & MFI & \\
\hline \multirow[t]{16}{*}{ Loan Amount wanted } & Below GHC 500 & Count & 3 & 4 & 7 \\
\hline & & $\%$ within loan amount wanted & $42.9 \%$ & $57.1 \%$ & $100.0 \%$ \\
\hline & & $\%$ within lending institution & $13.0 \%$ & $5.6 \%$ & $7.4 \%$ \\
\hline & & $\%$ of Total & $3.2 \%$ & $4.3 \%$ & $7.4 \%$ \\
\hline & GHC 500-1000 & Count & 3 & 28 & 31 \\
\hline & & $\%$ within loan amount wanted & $9.7 \%$ & $90.3 \%$ & $100.0 \%$ \\
\hline & & $\%$ within lending institution & $13.0 \%$ & $39.4 \%$ & $33.0 \%$ \\
\hline & & $\%$ of Total & $3.2 \%$ & $29.8 \%$ & $33.0 \%$ \\
\hline & GHC 1001- 2000 & Count & 5 & 26 & 31 \\
\hline & & $\%$ within loan amount wanted & $16.1 \%$ & $83.9 \%$ & $100.0 \%$ \\
\hline & & $\%$ within lending institution & $21.7 \%$ & $36.6 \%$ & $33.0 \%$ \\
\hline & & $\%$ of Total & $5.3 \%$ & $27.7 \%$ & $33.0 \%$ \\
\hline & +GHC 2000 & Count & 12 & 13 & 25 \\
\hline & & $\%$ within loan amount wanted & $48.0 \%$ & $52.0 \%$ & $100.0 \%$ \\
\hline & & $\%$ within lending institution & $52.2 \%$ & $18.3 \%$ & $26.6 \%$ \\
\hline & & $\%$ of Total & $12.8 \%$ & $13.8 \%$ & $26.6 \%$ \\
\hline \multirow[t]{4}{*}{ Total } & & Count & 23 & 71 & 94 \\
\hline & & $\%$ within loan amount wanted & $24.5 \%$ & $75.5 \%$ & $100.0 \%$ \\
\hline & & $\%$ within lending institution & $100.0 \%$ & $100.0 \%$ & $100.0 \%$ \\
\hline & & $\%$ of Total & $24.5 \%$ & $75.5 \%$ & $100.0 \%$ \\
\hline
\end{tabular}


The loan amount that the respondents wanted to borrow (as shown by the chi square test in Table 3 below), was also found to have a significant association with the average amount of cash the business generates per month $\left[x^{2}\right.$ (12) $=70.39, p<.001]$. This is confirmed by the spearman's correlation test which shows that as the amount of cash generated per month increased so did the loan amount applied for and vice versa $[$ rho $=.342, p<.001]$ This is an indication that these small businesses are only borrowing as much as they can afford and this is good for the lenders and the economy as a whole. Another explanation is that those businesses generating higher cash amounts per month are relatively bigger and thus have bigger financing needs, hence, their decision to apply for relatively larger amounts of credit.

Table 2. Chi square test between cash amount generated per month and amount of credit applied for

\begin{tabular}{llll}
\hline & Value & df & Assymp. Sig. (2- sided) \\
\hline Pearson Chi-square & $70.390^{\mathrm{a}}$ & 12 & .000 \\
Likelihood ratio & 80.541 & 12 & .000 \\
Linear-by-linear association & 17.174 & 1 & .000 \\
N of valid cases & 131 & & \\
\hline
\end{tabular}

Note. a. 6 cells (30.0\%) have expected count less than 5. The minimum expected count is 1.18 .

Table 4 below shows the proportion of the loan amounts that applicants actually received. About $28 \%$ of the 94 loan applicants obtained the full amount of the loans they wanted and were therefore not facing a credit constraint (unconstrained applicants). At the other extreme, almost $11 \%$ had their loan applications completely rejected and were classified as fully constrained and about $62 \%$ were classified as partially constrained since they only received fractions of the amounts they applied for.

Table 3. Proportion of loan amount actually received and constraint status of loan applicants

\begin{tabular}{cccc}
\hline Proportion of loan amount received & $\mathrm{N}=94$ & Valid $\%$ & Constraint status \\
\hline Zero & 10 & 10.6 & Fully constrained applicants \\
$<50 \%>$ zero & 16 & 17 & Partially constrained applicants \\
$50-75 \%$ & 31 & 33 & \\
$>76 \%$ but $<100 \%$ & 11 & 11.7 & \\
$100 \%$ & 26 & 27.7 & Unconstrained applicants \\
\hline
\end{tabular}

A total of about $72 \%$ of the loan applicants in this survey were thus credit constrained applicants. The extent of the constraint is much higher in this study relative to that reported in other developing countries like Mexico where Love and Sánchez (2009) report a relatively lower percentage (7\%) of completely rejected loan applications; they also reported a lower percentage (42\%) of totally constrained businesses. In Romania however, Chaves et al. (2001) established that the proportion of application completely rejected is $29 \%$ much higher than the 10.6\% reported in Table 4 above. The Wilcoxon's test (see Table 5 below) shows that a significant difference exist between the loan amount applied for and the amount received, $[Z=-4.03, p<.001]$. The amount received was significantly lower than what was applied for and according to Atieno (2001) this is an indication of the existence of loan quantity rationing in the credit market.

Table 4. Wilcoxon's test for difference between loan amount wanted and amount received test statistic ${ }^{\mathrm{b}}$

\begin{tabular}{ll}
\hline & Proportion of loan amount received- loan amount applied for \\
\hline $\mathrm{z}$ & $-4.032^{\mathrm{a}}$ \\
Asymp. Sig. (2- tailed) & .000 \\
\hline
\end{tabular}

Note. a. Based on negative ranks; b. Wilcoxon Signed Ranks Test.

The chi square test conducted further shows that the possibility of being a constrained or unconstrained borrower did vary significantly based on the average monthly cash generated $\left[{ }_{X}^{2}(3)=13.04, p<.01\right]$ and the loan amount applied for $\left[x_{x}^{2}(3)=18.87, p<.001\right]$ (see Tables 6 and 7 below). Small businesses with the ability to generate larger cash amounts were more likely to receive the full loan amount desired and vice versa. For instance, about 
$73 \%$ of all unconstrained loan applicants were generating above GHC 1,000 a month whilst only $26.9 \%$ were generating monthly cash amounts of GHC 1,000 or less. Furthermore, about $81 \%$ of the unconstrained borrowers wanted loan amounts above GHC 1,000.

Table 5. Chi square test for constraint status and monthly cash amounts generated by business

\begin{tabular}{llll}
\hline & Value & df & Asymp. Sig. (2-sided) \\
\hline Pearson Chi- Square & $13.044^{\mathrm{a}}$ & 3 & .005 \\
Likelihood Ratio & 12.714 & 3 & .005 \\
Linear-by-Linear Association & 10.446 & 1 & .001 \\
N of Valid Cases & 94 & & \\
\hline
\end{tabular}

Note. a. 1 cells $(12.5 \%)$ have expected count less than 5 . The minimum expected count is 3.04 .

Table 6. Chi square test for constraint status and loan amount applied for

\begin{tabular}{llll}
\hline & Value & df & Asymp. Sig. (2- sided) \\
\hline Pearson Chi- Square & $18.873^{\mathrm{a}}$ & 3 & .000 \\
Likelihood ratio & 19.361 & 3 & .000 \\
Liner-by-Linear Association & 14.958 & 1 & .000 \\
N of Valid cases & 94 & & \\
\hline
\end{tabular}

Note. a. 1 cells (12.5\%) have expected count less than 5. The minimum expected count is 1.94 .

There are two implications here. Firstly, applicants desiring to borrow relatively smaller amounts are more likely to be constrained and secondly, the degree of the constraint is likely to be higher for such borrowers than those desiring larger amounts. This is quite surprising in that, lenders should be more capable to meet borrowing requirements involving smaller amounts than those involving larger amounts and the smaller the amount the lesser the consequences of default will be for the lender. However, earlier results revealed that respondents who desired to borrow smaller amounts are mostly those that generate relatively small amounts of cash per month from their businesses. Therefore, applicants seeking smaller amounts are relatively smaller and less credit worthy. This could be the reason why most of those desiring to borrow small amounts did face a greater probability of being constrained. In addition, the constraint status of the borrower had a significant association with the selected lending institution $\left[{ }_{x}^{2}(4)=9.8, p<.05\right]$; see Table 8 below. The degree of the credit constraint is higher for applicants seeking credit from universal banks than their counterparts seeking credit from MFIs. For instance, about $22 \%$ of all applicants who sought for credit from Universal Banks were completely turned down compared to only $7 \%$ of those who approached MFIs. Also, only $13 \%$ of universal bank loan applicants got the full amount applied for relative to the $32 \%$ of MFI loan applicants. The strict lending policies of the Universal Banks possibly are the underlying factors responsible for this difference. However, there was no significant association between the possibility of being a constrained or unconstrained borrower and the respondents' age, gender and level of education.

Table 7. Chi square test for constraint status and lending institution

\begin{tabular}{llll}
\hline & Value & df & Asymp. Sig. (2- sided) \\
\hline Pearson Chi-Square & $9.771^{\mathrm{a}}$ & 4 & .044 \\
Likelihood Ratio & 9.528 & 4 & .049 \\
Linear-by- Linear Association & 2.375 & 1 & .123 \\
N of Valid Cases & 94 & & \\
\hline
\end{tabular}

Note. a. 3 cells ( $30 \%)$ have expected count less than 5 . The minimum expected count is 2.45 .

To find out how reliable credit access is, participants were asked whether or not they are able to obtain credit anytime it is needed. Of the 94 loan applicants, about $46 \%$ indicated that they do not have reliable supply of credit compared to $30 \%$ with reliable supply. As much as an estimated $39 \%$ of respondent who received the full loan amount applied for, do not also have reliable supply vis-à-vis $48.6 \%$ of respondents who received less than the full amount. The most worrying issue is that, a large proportion of the most credit worthy loan applicants in 
this study (those obtaining the full amount) still faces problems of supply reliability.

\subsection{Constraint Status of Non-Loan Applicants}

Apart from the 94 participants who had applied for loans, there were 37 participants in this survey who did not apply for credit within the two year period leading to the time of the survey. Their credit constraint status could only be determined by examining the reasons why they did not apply for credit. Participants who stated that they did not need credit are considered unconstrained whilst those stating any other reason are constrained (Banerjee \& Duflo, 2004; Diagne, Zeller, \& Sharma, 2000; Love \& Sánche, 2009). Table 8 below shows that 27\% (10) of the non-loan applicants (non-applicants) did not apply for credit because they had no need for it and were appropriately classified as unconstrained non-applicants since they had no demand for credit. These are probably people who had their own funds to invest or did not have any profitable venture that would necessitate a demand for credit. The remaining 73\% (27) were constrained because though they needed credit (i.e., had a demand for credit), there were some factors (identified in Table 9 below) that prevented them from making a credit application.

Table 8. Reason for not applying for a loan and constraint status

\begin{tabular}{lccl}
\hline Reasons & Frequency & Valid percentage & Constraint status \\
\hline Don't need it & 10 & 27.0 & Unconstrained Non- applicants \\
Can't afford cost & 11 & 29.7 & Constrained Non-applicants \\
Could not find one that suits my needs & 8 & 21.6 & \\
Think I don't qualify & 3 & 8.1 & \\
Don't know where and how to get it & 2 & 5.4 & \\
Procedure time consuming & 2 & 5.4 & \\
Don't have required documents & 1 & 2.7 & \\
Total & 37 & 100 & \\
\hline
\end{tabular}

Of the 27 constrained non-applicants, the most important reported reason why they did not apply for credit is because they could not afford the cost involved (40.7\%) followed by the fact that: they could not find one that met their specific requirements $(29.6 \%)$ and those who think they are unqualified (11\%). The rest are displayed in Table 10 below. These reasons indicate that these respondents have sometime in the past applied for credit, made enquiries from friends or lenders and as such have an idea of what the requirements for credit are. The above confirms findings in Kenya that most non-applicants are credit constrained (Atieno, 2001). In a similar study amongst micro enterprises in Brazil, 39\% of respondent did not apply for credit due to lack of need for it whilst $61 \%$ reported other reasons (Kumar \& Francisco, 2005). The incidence of credit constraint amongst non-applicants in this current study is higher than that reported in the Kenyan study but lower than that in Brazil. In Kenya, Atieno (2001) reports that the most important reason for not applying for credit is the lack of information. This is expected as the study was conducted in rural Kenya. This current study was conducted in a major city (Kumasi) and one would rightly expect that information on where to get credit would not be much of a problem.

Table 9. Constrained non-applicants and the perceived causes of the constraint

\begin{tabular}{lcc}
\hline Causes & Frequency & Valid percentage \\
\hline Can't afford cost & 11 & 40.7 \\
Could not find one with terms that suits my needs & 8 & 29.6 \\
Think I don't qualify & 3 & 11.1 \\
Don't know where and how to get it & 2 & 7.4 \\
Procedure time consuming & 2 & 7.4 \\
Don't have required documents & 1 & 3.7 \\
Total & 27 & 100 \\
\hline
\end{tabular}

Given the high interest rates of $25 \%$ and above in Ghana (Kpodo \& Valdmanis, 2010), it is not difficult to understand why it is the most reported barrier to participation in the credit market. This confirms findings of Love and Sánchez (2009) that higher interest rates and transaction cost are the main barriers to credit market participation by small enterprises. In Brazil, Kumar and Francisco (2005) also report cost as the main reason why 
some micro-enterprises do not apply for credit. Apart from cost been a major barrier to credit access, the above result also appears to suggest that lenders provide standardised products. Almost $30 \%$ of constrained non-applicants did not apply for credit because they could not find facilities with the right amounts, maturities and repayment schedules that suit their needs. These people would rather not seek credit than to go for credit that does not meet their needs. The lack of tailor-made products could actually create repayment problems for borrowers. The problem of documentary requirements was not a major cause of the constraint reported by constrained non-applicants (3.7\%).

\subsection{Demand and Supply Constraints}

A detailed breakdown of the above results into the supply and demand side components is provided in the Table 11 below. From the results discussed so far in this study, 72.5\% (95) of all the 131 small businesses surveyed are credit constrained (involves 68 loan applicants and 27 non-applicants). Out of the 95 constrained respondents, 93 of them (97.9\%) faced a supply-side constraint. These included the partially and fully constrained applicants as well as non -applicants who did not apply for credit because of: high cost, lack of tailor made facilities; fear of rejection (those who think they don't qualify); process inconveniences and lack of required documents). Only 2 respondents $(5.4 \%)$ reported a demand side constraint (those who cited lack of knowledge of where and how to get credit). On the other hand, 36 participants (27.5\% of all participants) made up of 26 loan applicants and 10 non-applicants were unconstrained. Hence, the small businesses surveyed face predominantly a supply-side constraint. Demand-side constraints are almost non-existent amongst the sample surveyed. This also confirms the argument in the literature that credit constraint is mainly caused by supply-side factors (Atieno, 2001). Contrary to the results of this study Chaves et al. (2001) found that demand side factors were responsible for the limited participation of the small enterprises in the Romanian credit market.

Table 10. A summary of the credit constraint amongst small enterprises

\begin{tabular}{|c|c|c|c|c|c|c|c|}
\hline \multicolumn{3}{|c|}{ Loan Applicants = 94} & \multicolumn{3}{|c|}{ Non-applicants $=37$} & \multicolumn{2}{|c|}{ Total $=131$} \\
\hline Status & Frequency & Classification & $\begin{array}{l}\text { Reasons for not } \\
\text { applying for loan }\end{array}$ & Frequency & Status & $\begin{array}{l}\text { Participants' } \\
\text { Status }\end{array}$ & Frequency \\
\hline $\begin{array}{l}\text { Not } \\
\text { constrained }\end{array}$ & $27.7 \%(26)$ & $\begin{array}{l}\text { Unconstrained } \\
\text { Loan Applicants } \\
27.3 \%(26)\end{array}$ & Don't need a loan & $27 \%(10)$ & $\begin{array}{l}\text { Not } \\
\text { constrained } \\
27 \%(10)\end{array}$ & $\begin{array}{l}\text { Unconstrained } \\
\text { participants }\end{array}$ & $\begin{array}{l}27.5 \\
(36 \%)\end{array}$ \\
\hline $\begin{array}{l}\text { Partially } \\
\text { Constrained }\end{array}$ & $61.7 \%(58)$ & $\begin{array}{l}\text { Supply-side } \\
\text { constraint }\end{array}$ & Cost (unaffordable) & $\begin{array}{l}29.7 \% \\
(11)\end{array}$ & $\begin{array}{l}\text { Supply-side } \\
\text { constrained }\end{array}$ & $\begin{array}{l}\text { Constrained } \\
\text { Participants }\end{array}$ & $\begin{array}{l}72.5 \% \\
(95)\end{array}$ \\
\hline $\begin{array}{l}\text { Fully } \\
\text { constrained }\end{array}$ & $10.6 \%(10)$ & $72.3 \%(68)$ & $\begin{array}{l}\text { Lack of flexibility in } \\
\text { terms and conditions }\end{array}$ & $21.6 \%(8)$ & $67.6 \%(25)$ & & \\
\hline \multirow[t]{6}{*}{ Total } & $100 \%(94)$ & $100 \%(94)$ & $\begin{array}{l}\text { Believe I don’t } \\
\text { qualify }\end{array}$ & $8.1 \%(3)$ & & & \\
\hline & & & Inconvenience & $5.4 \%(2)$ & & & \\
\hline & & & Lack of information & $5.4 \%$ & Demand-side & & \\
\hline & & & on where and how to & (2) & constraint & & \\
\hline & & & get a loan & & $5.4 \%(2)$ & & \\
\hline & & & Total & $100 \%(37)$ & $100 \%(37)$ & & \\
\hline
\end{tabular}

Source: Field Data.

\section{Conclusions and Recommendation}

Despite the high desire for credit observed amongst small enterprises, access to credit remains the most important problem of majority of these enterprises. Contrary to opinion that such enterprises rely on informal sources of funding, this research has shown their active involvement in formal credit markets to fund their business activities. Majority of small enterprises tend to seek for credit from MFIs rather than Commercial Banks. Majority of the small enterprises receive a significantly lower amount of credit than they would have wanted. Furthermore, most participants were applying for credit amounts that were related to the amount of revenue they are able to generate from business activities on a monthly basis. This is an indication that they are not as risky as traditionally perceived. The incidence of credit constraint was related to selected lending institution, the amount of cash the business generate in a month and the loan amount participants desired. In addition, there is no reliability in credit access. Thus even enterprises that reported no credit constraint at the 
time of the research could encounter a constraint the next time they apply for credit. A high level of constraint was observed amongst participants who reported no credit market activity; cost of credit and lack of tailor-made products were the main constraint factors for the credit constraint reported by non-loan applicants.

Finally, the credit constraint encountered by small enterprises in this study almost entirely emanates from supply-side barriers; the demand side is almost non-existent. Hence policies for enhancing credit access should be focused on the supply-side. Creating an environment that will increase competition amongst lenders could improve efficiency, reduce cost of borrowing and enhance access by making credit more affordable. Since access to credit is found to be higher amongst participants seeking credit from MFIs compared to those seeking credit from commercial banks, facilitating the spread of MFIs across the country could be a sure way of enhancing credit access. The very small businesses generating only a few hundred cedis per month should be the focus of any intervention policies as the incidence and degree of constraint is higher amongst them.

\section{References}

Abor, J., \& Biekpe, N. (2006). Small Business Financing Initiatives in Ghana. Problems and Perspectives in Management, 4(3), 69-77.

Abor, J., \& Quartey, P. (2010). Issues in SME Development in Ghana and South Africa. International Research Journal of Finance and Economics, 39(1), 218-228.

Aryeetey, E. (1998). Informal Finance for Private Sector Development in Africa. Economic Research Papers No. 41, The African Development Bank, Abidjan.

Atieno, R. (2001). Formal and informal institutions' lending policies and access to credit by small-scale enterprises in Kenya: An empirical assessment. AERC Research Paper 111, African Economic Research Consortium, Nairobi.

Ayyagari, M., Beck, T., \& Demirgüc-Kunt, A. (2003). Small and Medium Enterprises across the Globe. World Bank Policy Research Working Paper 3127, August, Washington D.C.

Bahar, H. (2001). Financing for Micro Enterprises, Small, Medium-Sized and Cottage Industries, Bangladesh Perspective. A Paper Presented At The ESCAP-ADB Joint Workshop On Mobilizing Domestic Finance For Development: Reassessment of Bank Finance and Debt Markets In Asia and The Pacific, Bangkok, 22-23 November.

Banerjee, A., \& Duflo, E. (2004). Do Firms Want to Borrow More? Testing Credit Constraints Using a Directed Lending Program. Department of Economics, MIT.

Bendig, M., Giesbert, L.,. \& Steiner, S. (2009). Savings Credit and Insurance, Household Demand for Formal Financial Services in Rural Ghana. BWPI Working Paper 76, Manchester.

Berg, E. (2010). Are Poor Households Credit-constrained or Myopic? Evidence from a South African panel. Centre for the Study of African Economies, Department of Economics, University of Oxford, CSAE WPS/2010-31.

Bigsten, A., Collier, P., Dercon, S., Fafchamps, M., Gauthier, B., Gunning, J. W., \& Oduro, A. (2003). Credit Constraints in Manufacturing Enterprises in Africa. Retrieved from http://www.economics.ox.ac.uk/CSAEadmin/workingpapers

Caprio, G., \& Honohan, P. (2001). Finance for Growth, Policy Choices in a Volatile World. A World Bank Policy Research Report. New York: Oxford University Press Inc. http://dx.doi.org/10.1596/0-1952-1605-9

Chavez, R., Sanchez, S., Schor, S., \& Tesliuc, E. (2001). Financial Markets Credit Constraints and Investment in Rural Romania. World Bank Technical Paper No. 499, Europe and central Asia Environmental and Socially Sustainable Development Series, Washington DC. http://dx.doi.org/10.1596/0-8213-4928-7

Chen, K., \& Chivakul, M. (2008). What Drives Household Borrowing and Credit Constraints? Evidence from Bosnia and Herzegovina. IMF Working Paper, WP/08/202. http://dx.doi.org/10.5089/9781451870602.001

Claessens, S. (2006). Access to Financial Services: A Review of the Issues and Public Policy Issues. World Bank Research Observer, 21(2), 207-240. http://dx.doi.org/10.1093/wbro/lk1004

Diagne, A., Zeller, M., \& Sharma, M. (2000). Empirical Measurements of Households' Access To Credit And Credit Constraints In Developing, Countries: Methodological Issues And Evidence. FCND DISCUSSION PAPER NO. 90, Washington DC.

Domeher, D., \& Abdulai, R. (2012a). Access to Credit in the Developing World: Does Land Registration Matter. 
Third World Quarterly, 33(1), 161-175. http://dx.doi.org/10.1080/01436597.2012.627254

Kpodo, K., \& Valdmanis, R. (2010). Analysis: Ghana Credit Bottlenecks Hinder Local Businesses Growth. Retrieved from http://www.reuters.com/article/2010/08/12/us-ghana-loans-analysis-idUSTRE67B3EM20100812

Kumar, A., \& Francisco, M. (2005). Enterprise Size, Financing Patterns, and Credit Constraints in Brazil Analysis of Data from the Investment Climate Assessment Survey. World Bank Working paper no. 49, Washington DC.

Love, I., \& Sánchez, S. (2009). Credit Constraints and Investment Behaviour in Mexico's Rural Economy. the World Bank, Development Research Group, Policy Research Working Paper 5014.

Melzer, C. (2007). The Importance of Bank Loan Supply for Real Economic Activity in the Euro Area-A Panel Data Analysis, Bonn. University of Bonn.

Ruiz-Tagle, J. (2005). Borrowing in Developing Countries: Who can Access Credit and at What Cost? Jesus College, University of Cambridge.

Stiglitz, J., \& Weiss, A. (1981). Credit Rationing in Markets with Imperfect Information. The American Economic Review, 71(3), 393-410.

World Bank. (2006). Doing Business Report: Creating Jobs. Washington DC.

World Bank. (2008). Finance for all, Policies and Pitfalls in Expanding Access. A World Bank Policy Research Report, Washington DC.

\section{Copyrights}

Copyright for this article is retained by the author(s), with first publication rights granted to the journal.

This is an open-access article distributed under the terms and conditions of the Creative Commons Attribution license (http://creativecommons.org/licenses/by/3.0/). 